\title{
Determination of Skills Acquisition and Professional Knowledge Acquired by Nigerian Graduates through the Current University Curriculum
}

\author{
Ola Adebayo BTech \\ Department of Entrepreneurship, Joseph Ayo Babalola University, Ikeji-Arakeji, Osun State, Nigeria
}

\begin{abstract}
The need for entrepreneurship education started towards the end of $19^{\text {th }}$ century and gained increased recognition in the closing decades of the $20^{\text {th }}$ century among economists as a significant driver of improvement in societal welfare. The study was intended to assist the Universities and the authority concerned in the development, drafting, and implementing innovative models for new curriculum for historically underserved Nigerian University undergraduates. The work provides extensive data using NYSC corps members as respondents, covering seven states NYSC secretariats. The data for the work was generated, employing the instruments of questionnaire (field survey) method and was able to determine the standard and quality of the current University curriculum, also its capability and limitations in the area of entrepreneurship programme. Analysis was made based on primary data collected from all seven states that were represented by the coverage areas. The results of the research as analysed was presented and the significance of the results tested according to the objectives of the research. The paper looks at the course specialization, and level of education and disciplines attained by the corps members in order to be able to see why it is difficult for graduates to secure jobs. The work was carried out to highlight the gap between the theory and the skills with technical and professional training that is missing in our university curriculum. Conclusion was drawn based on the research findings and recommendation that were appropriate being put forward to the authority concerned.
\end{abstract}

Key Words: Nysc Corps' members, undergraduate curriculum, course specialization and qualification

\section{Introduction}

Entrepreneurial education has long been considered a significant education or training for economic growth and development, simply because it provides many job opportunities. As a result of positive impact of entrepreneurial skills and training recent decades have witnessed a tremendous rise in entrepreneurial education at various tertiary institutions (university and polytechnics' and colleges) around the world.

The paper highlights the insignificant level of entrepreneurial education across different fields of endeavour as it can be seen in Nigerian Universities through this research work. Whereas, finding revealed that entrepreneurial education is best received in the school settings; also learning by doing is seen as the best approach.(Muraina, Aiyegbusi etal 2012).

The lingering problem of graduates unemployment in Nigeria as a result of higher education curriculum that is wobbly and irrelevant to the need of the society. Over the years, the tertiary institutions courses of study have emphasized the theory above practical.
Some of the traditional barriers to entrepreneurship education development in Nigeria are e.g.- Course discrimination, Hate for skills and technical training knowledge by the leaders in the sector, Prejudice by the conservative academics against any new knowledge that is not totally theoretical, General lack of entrepreneurship education by Nigerian academics in putting together very relevant and an enduring entrepreneurship curriculum for our Universities.

Joseph Ayo Babalola University being the oldest University in Nigeria - (since 2006 to date) running a degree programme on entrepreneurship. However, about 3 other Federal Universities have been approved to run entrepreneurship programmenamely: Federal University of Technology Akure (FUTA), Federal University of Agriculture Abeokuta (FUNNAB) etc.

This study therefore fills an important information gap to assist the University and the authority concerned in the education sector in drafting entrepreneurship undergraduates curriculum that will stand the test of time.

Hence, the need for the development of the entrepreneurial education in higher institution in the 
country to resolve the perennial problem of graduates' unemployment.

\section{Literature Review}

Jean-Baptiste Say, a French economist, coined the word "entrepreneur" in the $19^{\text {th }}$ century, he defined an entrepreneur as "one undertakes an enterprise especially, a contractor, acting as intermediary between capital and labour" According to Encarta dictionaries, an entrepreneur is somebody who initiates or finances new commercials enterprise. The entrepreneur is an innovator, one who carries a combination of the following: The introduction of a new product; the opening of a new market, the conquest of new sources of materials; and the organization of new industry.

The term Entrepreneurship education implies that entrepreneurship can be taught and indeed this idea has been a popular topic for research. Among others, the angles of research include whether entrepreneurship can be taught (Dana, 2001; Henry et al, 2005); the impact of the academic career training has on the ability to innovate and recognize opportunities (Graig et al, 2006); measurement of individual's leaning towards entrepreneurship using the Enterprising Managers Assessment Questionnaire, (EMAQ).

Deamer Earle, (2004); emerging trends and challenges for entrepreneurship education in the $21^{\text {st }}$ Century (Kuratko, 2003); and development in the use of words to describe courses in entrepreneurship education (Gibb, 1993, 2000, Gibb and Nelson, 1996 and Henry et al, 2005). The findings of these studies provide a collage of perspectives from which we can draw insights on entrepreneurship education.
Henry et. al (2005), in their two- part paper reports the lack of uniformity in entrepreneurship education and calls for the specification of programme objectives at the outset to facilitate the assessment of learning outcomes, a mixed approach to evaluation consisting of both objective and subjective evaluation.

\section{Research Methodology}

Data for this study were collected mainly from primary source through the use of questionnaires, and concentrated only on the current serving corps members who have gone through the current archaic curriculum and that it is believed that they would be in a better position to tell us what we need as a nation in our undergraduates university curriculum.

The study furnishes policy makers, program implementers and the public at large with relevant information. On the class of graduates Nigerian universities are producing-(see table 1 and figures 1 to 9 below).

The research method put forward two sets of simple questions: (i)- The Level of qualification (ii)Course specialization This, it is believed would assist the researcher in determining the level of entrepreneurial knowledge gained from the university by the graduates.

The total number of questionnaire administered were one thousand seven hundred and fifty $(1,750)$, sample size covering Kwara and the six southwestern NYSC States Secretariat corps members, that were then on service year.(Batches A, B, and C). While1,339 respondents response were received. At a response rate of $76.5 \%$.

\section{Results}

Table: 1 Respondents Response to Course Specialization.

\begin{tabular}{llllllllllll}
\hline LOCATION & $\begin{array}{l}\text { ENG/T } \\
\text { E }\end{array}$ & MgS & SoS & NATS & HUM & AGR & URP & A/D & LAW & MED & EDU \\
\hline OGUN 244 & 18 & 43 & 28 & 74 & 19 & 14 & 5 & 7 & 2 & 2 & 28 \\
OYO 243 & 15 & 74 & 28 & 53 & 12 & 11 & 4 & 4 & 6 & 8 & 23 \\
KWARA 207 & 14 & 82 & 11 & 38 & 10 & 13 & 15 & 1 & 6 & 2 & 7 \\
EKITI 191 & 16 & 35 & 34 & 30 & 16 & 6 & 11 & 7 & 2 & 16 & 15 \\
ONDO 189 & 5 & 44 & 12 & 32 & 16 & 24 & 14 & 4 & - & 13 & 14 \\
OSUN 180 & 16 & 32 & 33 & 33 & 16 & 12 & 10 & 1 & 6 & 6 & 13 \\
LAGOS 85 & 3 & 12 & 25 & 15 & 6 & 5 & 3 & 4 & 1 & 2 & 8 \\
Total & 87 & 322 & 171 & 275 & 95 & 85 & 62 & 28 & 23 & 49 & 108 \\
\hline
\end{tabular}




\section{Course Specialization of Respondents:}

Eleven Colleges/Faculties that were discovered in the study were indicated in table 1 . The table consists of 12 columns .Column1 heading is represented by location (coverage areas). Columns 2-12 headings were represented by (ENG/TE) Engineering/ Technology, (MGS) Management Sciences ,(SOS) Social Sciences.
(NATS) Natural Sciences, (HUM) Humanities, (AGR) Agricultural Sciences, (URP) Urban and Regional Planning, (A/D) Arts \& Design, (LAW) Law, (MED) Medicine, and (EDU) Education respectively. The bottom line of table 1 being the ( Total) sum of the course/specialization were converted to percentage ratios in table 2 below.

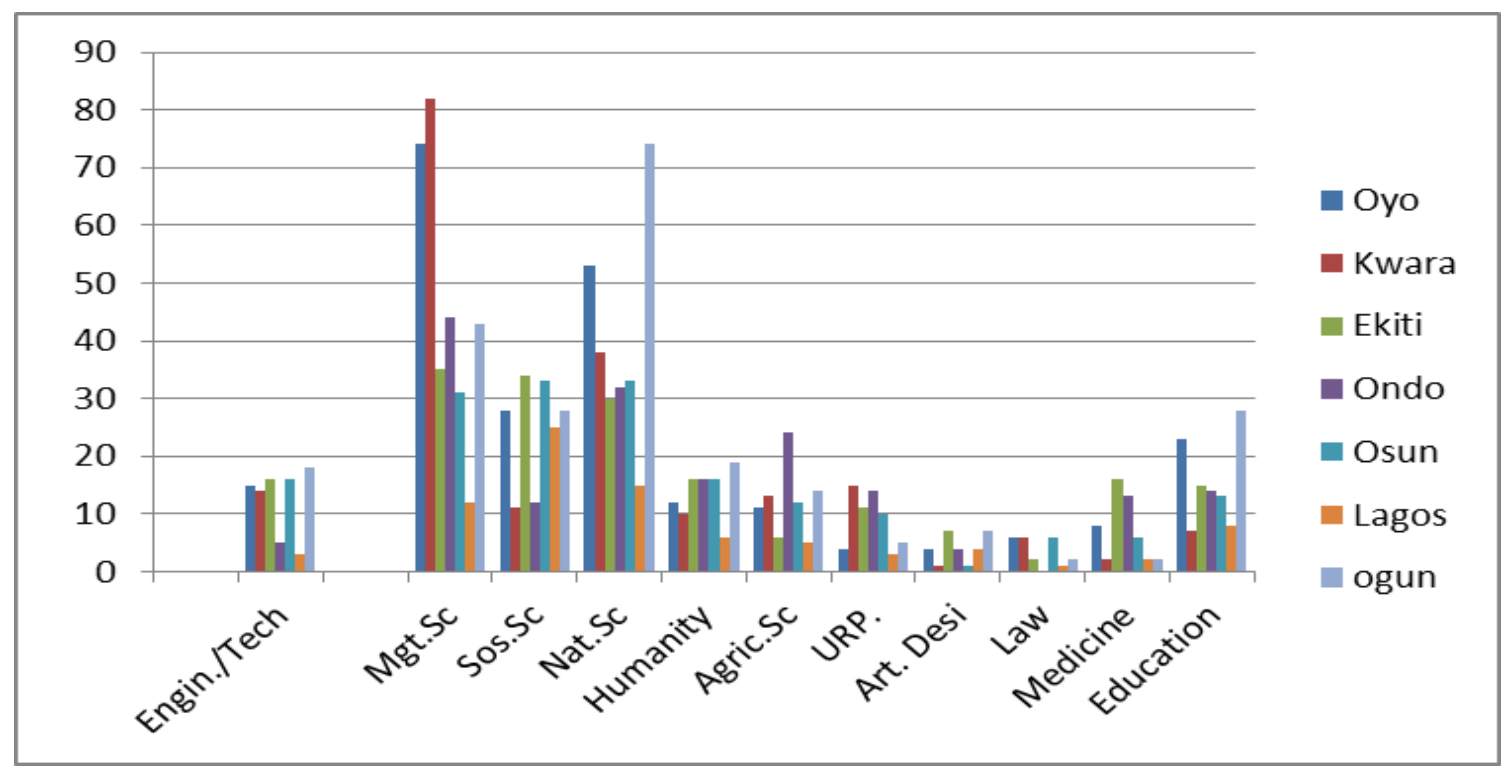

Figure 1. Distribution of Course Specialization of the respondents: The eleven colleges or faculty courses combined.

Table 2. Represents percentage ratio based on respondents response data in table 1.

\begin{tabular}{llllllllllll}
\hline SNS & ENG/TE & MgS & SOS & NATS & HUM & AGR & URP & A/D & LAW & MED & EDU \\
\hline OGUN 224 & 7.5 & 17.9 & 11.7 & 30.8 & 7.9 & 5.8 & 2.1 & 2.9 & 0.8 & 0.8 & 11.7 \\
OYO 243 & 6.3 & 31.1 & 11.8 & 22.3 & 5.0 & 4.6 & 1.7 & 1.7 & 2.5 & 3.3 & 9.7 \\
KWARA 207 & 7.0 & 41.2 & 5.5 & 19.1 & 5.0 & 6.5 & 7.5 & 0.5 & 3.0 & 1.0 & 3.5 \\
EKITI 191 & 8.4 & 18.5 & 18.0 & 15.9 & 8.4 & 3.2 & 5.8 & 3.7 & 1.0 & 8.4 & 7.9 \\
ONDO 189 & 2.8 & 24.7 & 6.7 & 18.0 & 9.0 & 13.4 & 7.8 & 2.2 & 0.0 & 7.3 & 7.8 \\
OSUN 180 & 9.0 & 18.0 & 18.5 & 18.5 & 9.0 & 6.7 & 5.6 & 0.5 & 3.3 & 3.3 & 7.3 \\
LAGOS 85 & 3.5 & 14.3 & 29.8 & 17.8 & 7.1 & 5.9 & 3.5 & 4.8 & 1.2 & 2.4 & 9.5 \\
Mean & 6.6 & 24.8 & 13.2 & 20.9 & 7.2 & 6.5 & 7.5 & 0.5 & 3.0 & 1.0 & 3.5 \\
Mode & 6.3 & 31.1 & 11.8 & 22.3 & 5.0 & 4.6 & 1.7 & 1.7 & 2.5 & 3.3 & 9.7 \\
Median & 7.0 & 41.2 & 5.5 & 19.1 & 5.0 & 6.5 & 7.5 & 0.5 & 3.0 & 1.0 & 3.5 \\
\hline
\end{tabular}

Mean in line 9 shows an intermediate or average level results of Respondents response data in the above table.

Mode in line 10 shows the greatest frequency value of results of Respondents response data in the table
Median in line 11shows the straight line or plane value that divides the data longitudinally into symmetrical haves was determined in table 2 above 1 


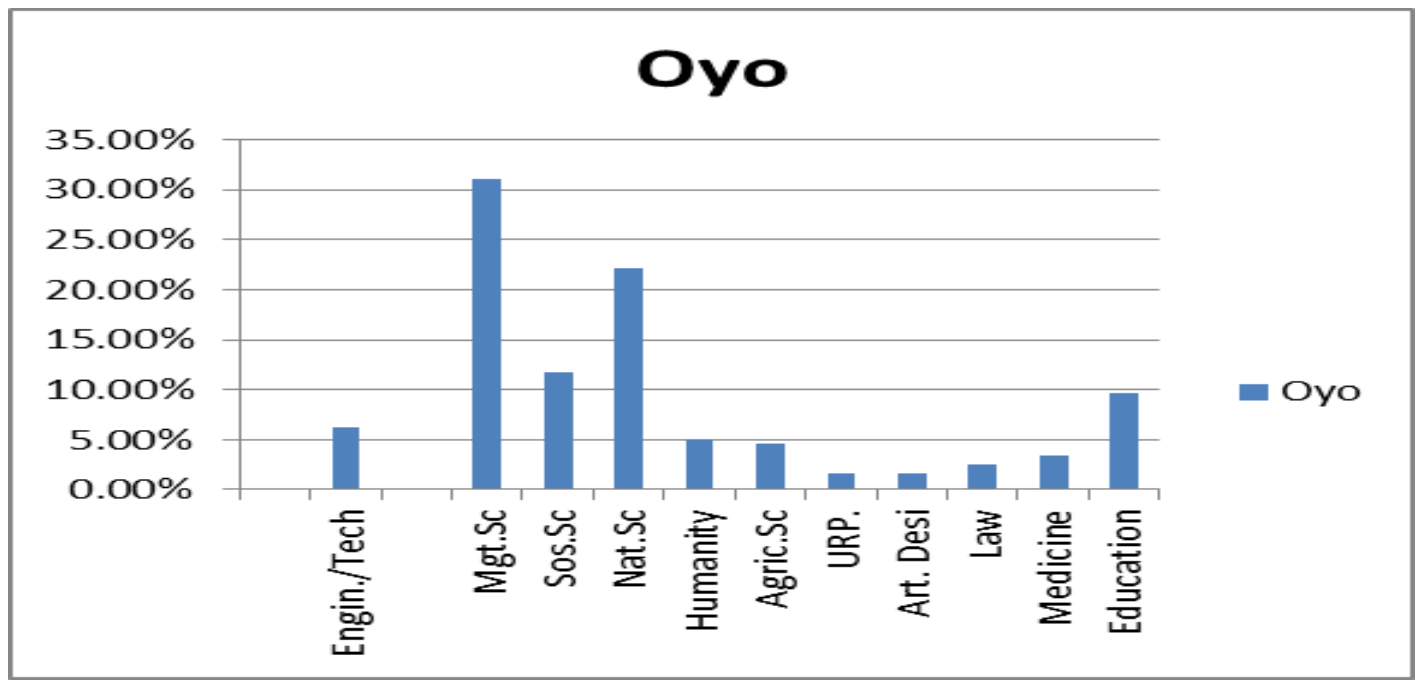

Figure. 2: Colleges/ Faculty Courses.

It can be seen from the bar chart that out of eleven colleges/faculties. Management sciences' graduates contributed $31.1 \%$ out of one hundred percent.
Followed by $22.3 \%$ for the Natural sciences. URP and Arts and Design contributed $1.7 \%$ each of respondents.

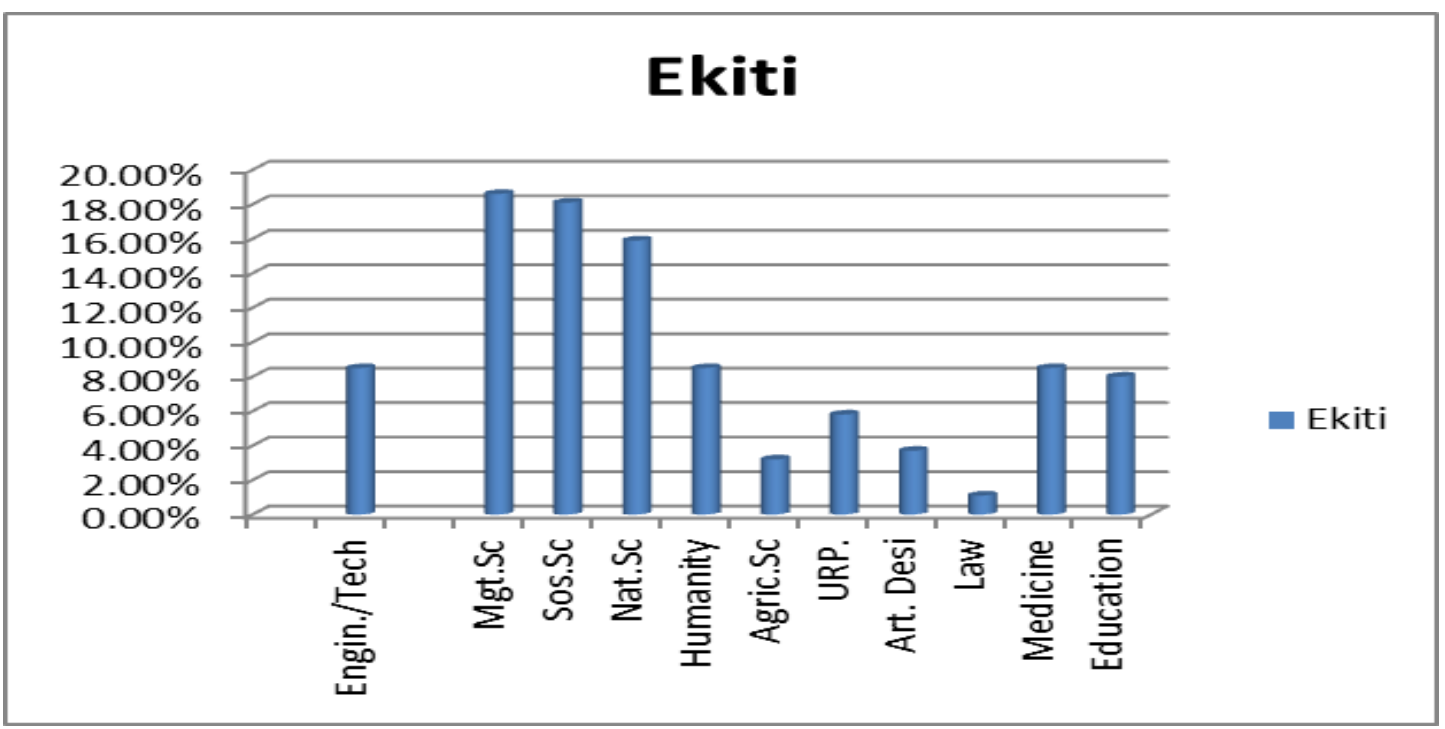

Figure 3: Colleges / Faculty Courses. Course distribution within Respondents in Ekiti state in percentages.

From the bar chart ,figure 3 for Ekiti. Management sciences contributed $18.5 \%$ of graduates' respondents and Social sciences contributed almost the same number of graduates with Management sciences18.4\% . Again Natural sciences contributed 15.9\%.of graduates' respondents, while Law faculty contribution was $1.0 \%$ of respondents. graduates Course distribution within Respondents in Ondo state in percentages 


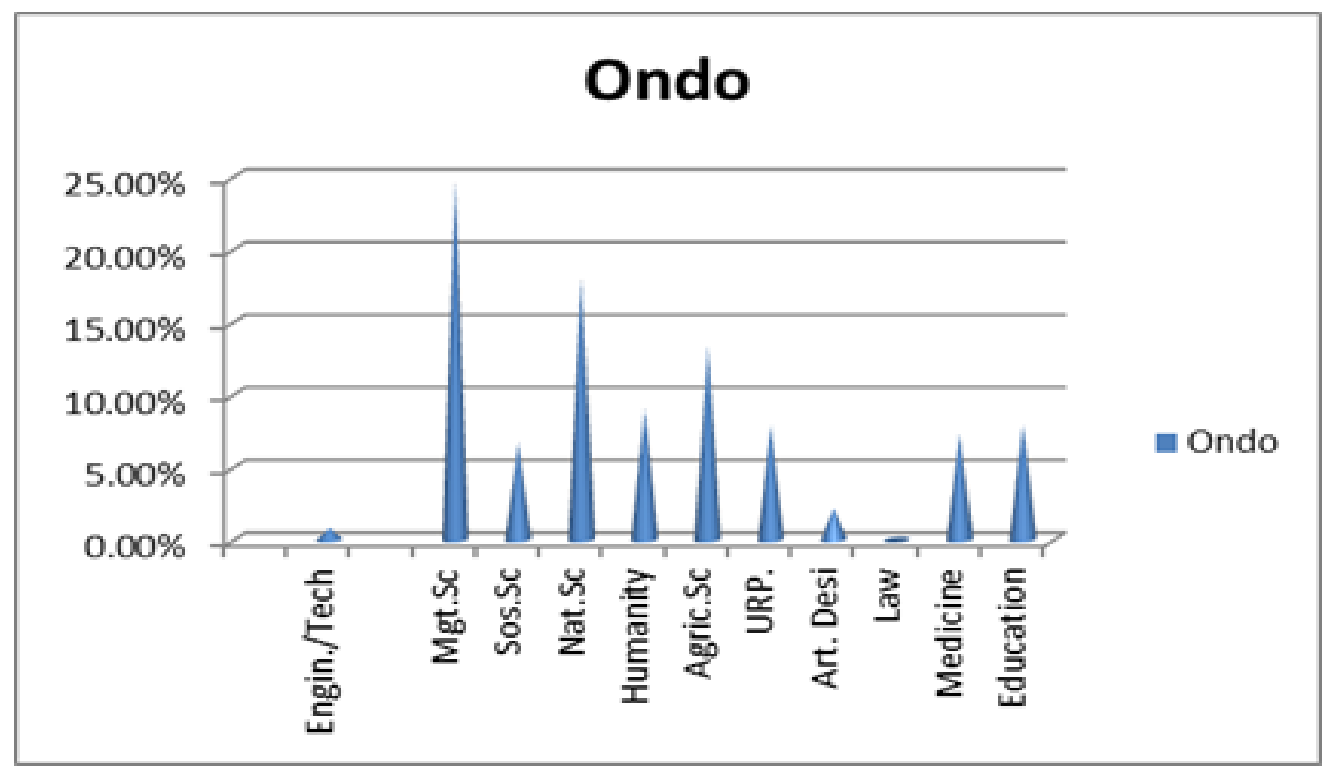

Figure 4: Colleges / Faculty Courses.

In figure 4 Management sciences again contributed 24.7\%, Natural sciences $18.0 \%$, and no contribution from the faculty of Law

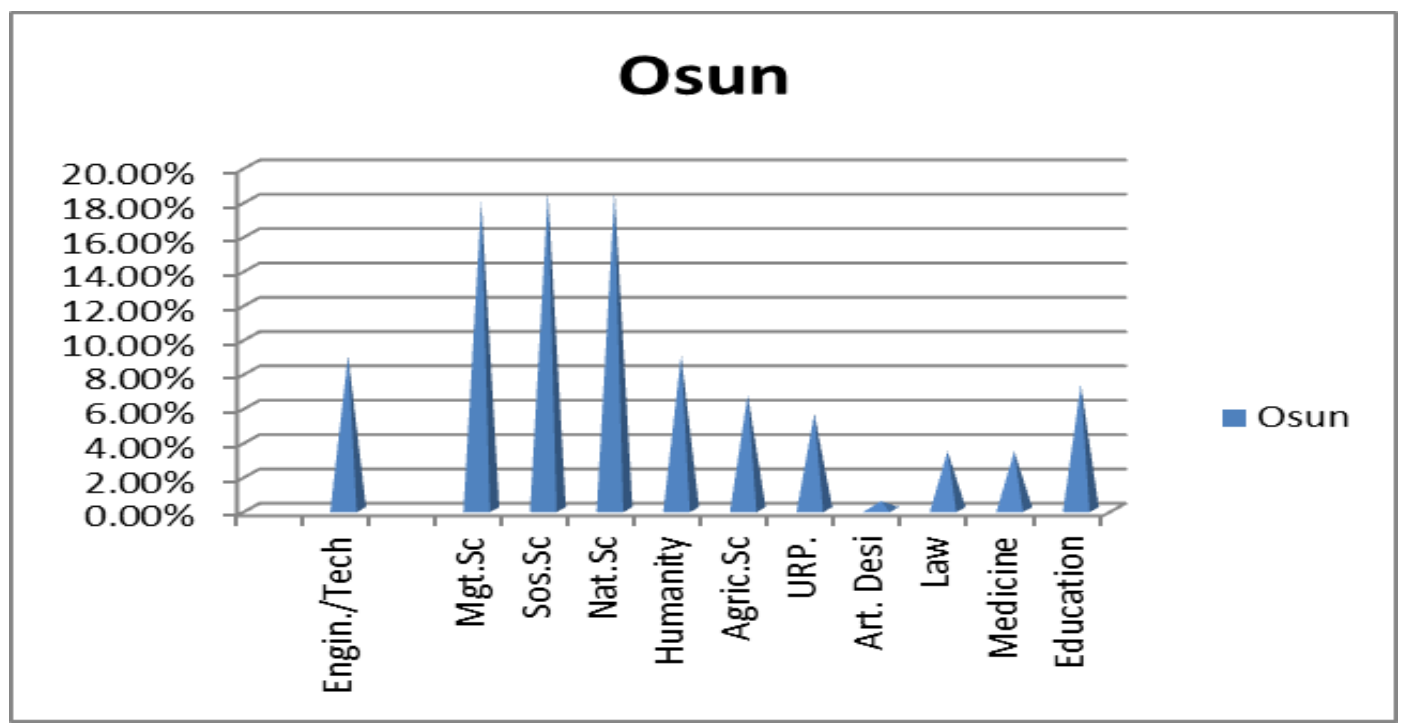

Figure 5. Colleges/ Faculty Courses: Course distribution within Respondents in Osun statein percentage.

Again, Management sciences' contribution to the overall production of graduates fig. 5 stands at $18.0 \%$, while Social Sciences and Natural sciences colleges contributed $18.5 \%$ each. 


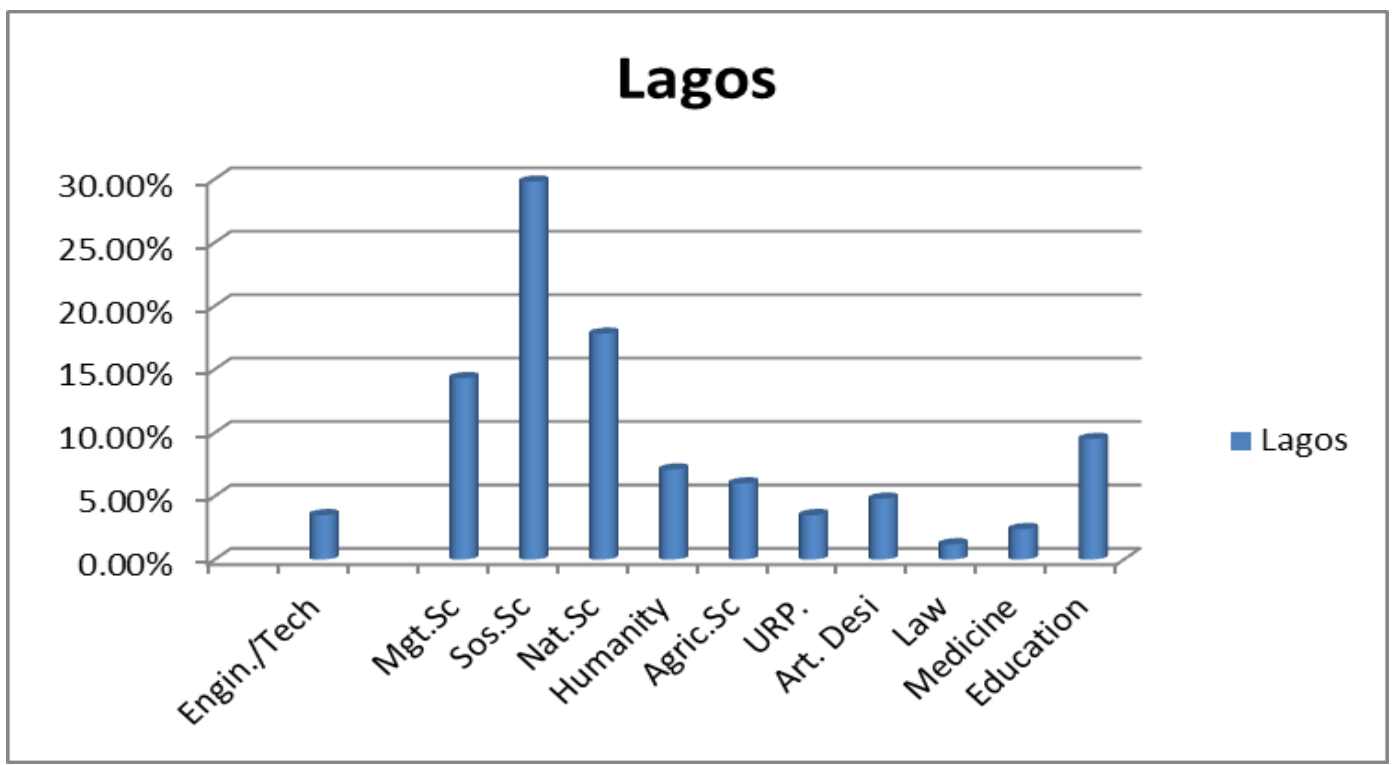

Figure 6. Colleges/ Faculty Courses: Course distribution within Respondents in Lagos statein percentages.

Faculty of social sciences contributed $29.8 \%$ of the total number of graduates, while $17.8 \%$ were graduates of the faculty of natural sciences. $1.2 \%$ was recorded against the Law faculty.

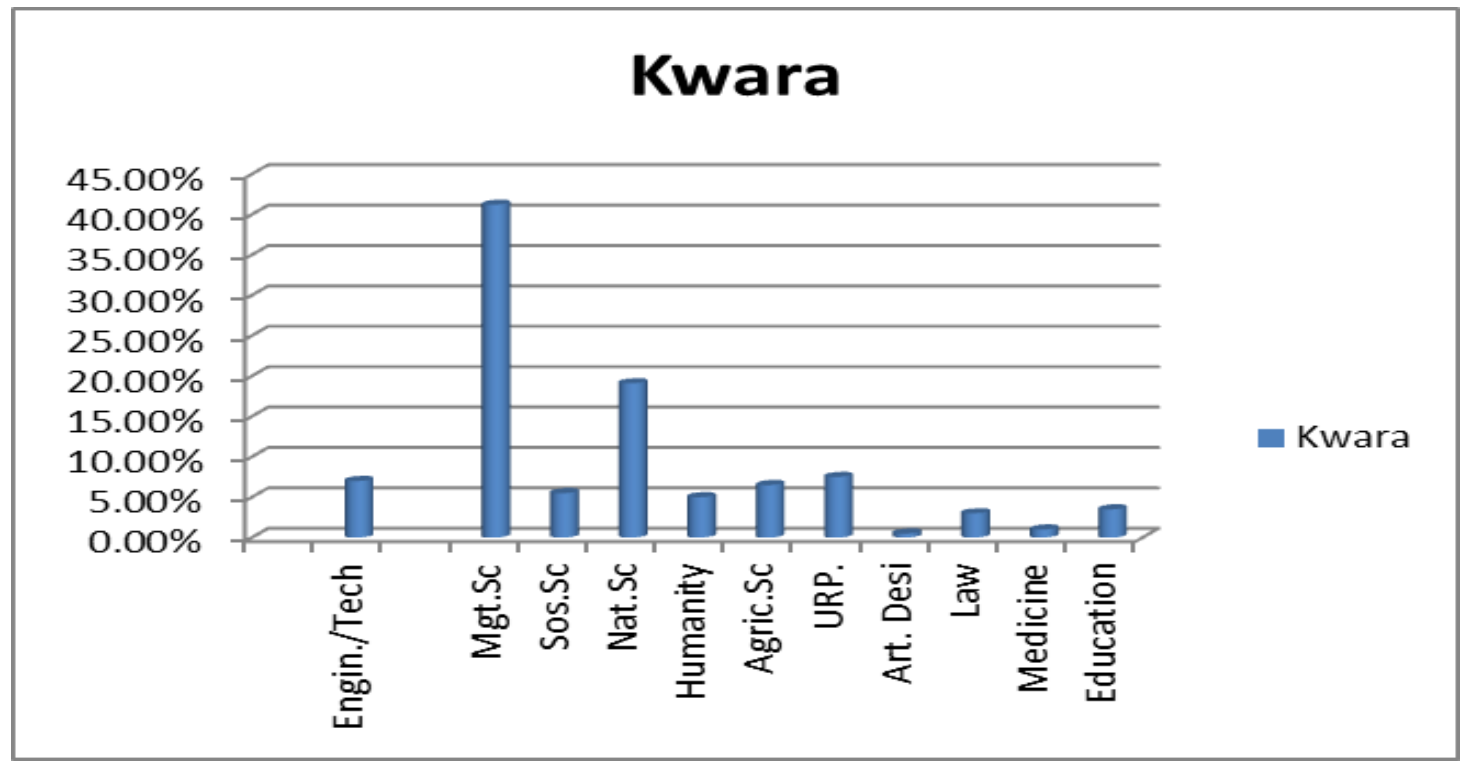

Figure 7: Colleges / Faculty Courses: Course distribution within Respondents in Kwara state in percentages.

In Kwara, Faculty of Management Sciences contributed $41.2 \%$, whilst natural sciences contributed the second highest ratio of $19.1 \%$.of graduates' respondents 


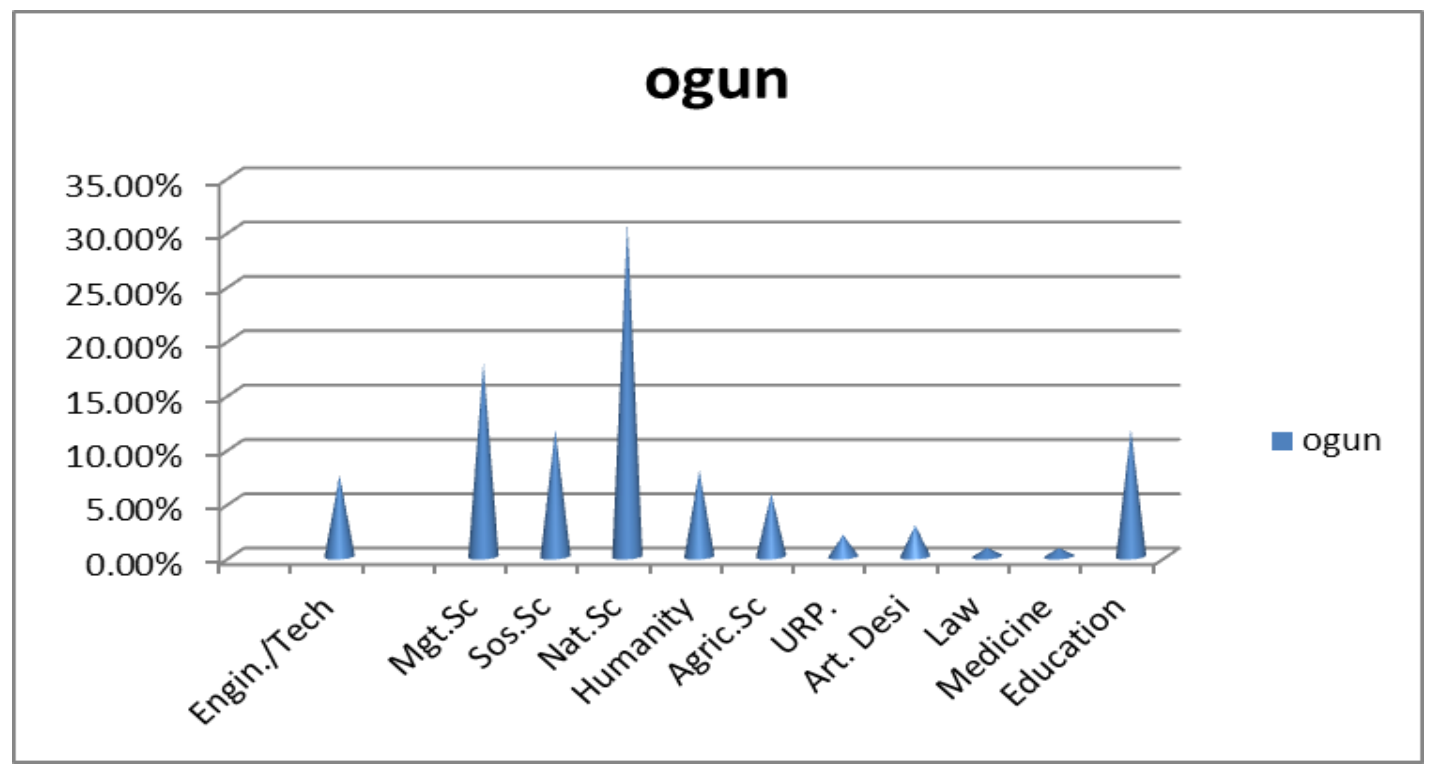

Figure 8. Colleges/ Faculty Courses: Course distribution within Respondents in Ogun state in percentages

From ogun state respondents, natural science contributed the highest share of $30.8 \%$, while Law and Medicine contributed $0.0 \%$ each.
In this section, the results of the research as analysed was presented and the significance of the results tested according to the objective of the research

\section{Demographic profile of respondents}

Tables 3. Profile of Respondents as regards Courses/Disciplines.

\begin{tabular}{llllll}
\hline S/N & Courses/Disciplines. & Scores & Percentage & Valid \% & $\begin{array}{l}\text { Cummulative } \\
\text { Percentage }\end{array}$ \\
\hline 1. & Natural sciences with related courses & 275 & 21.1 & 21.1 & 21.1 \\
2. & Engineering/technology related courses & 87 & 6.7 & 6.7 & 27.8 \\
3. & Agricultural with related courses & 85 & 6.4 & 6.5 & 34.3 \\
4. & Urp with other related courses & 62 & 4.8 & 4.8 & 39.1 \\
5. & Arts \& design with other related courses & 28 & 2.1 & 2.1 & 41.2 \\
6. & Law & 23 & 1.8 & 1.8 & 43.0 \\
7. & Medicine with related courses & 49 & 3.7 & 3.7 & 46.7 \\
8. & Management sciences with related courses & 322 & 248 & 24.7 & 71.4 \\
9. & Social sciences with related courses & 171 & 13.1 & 13.1 & 84.5 \\
10. & Education with related course & 108 & 8.3 & 8.3 & 92.8 \\
11. & Humanities with related courses & 95 & 7.3 & 7.3 & 100.0 \\
12. & Total & 1,305 & 100.0 & 100.0 & \\
\hline
\end{tabular}

The above shows that greater proportion of graduates produced by our universities as represented by $24.7 \%$ read management science. This was followed by those who read natural sciences representing $21.1 \%$ of the total sample, while those who read social sciences represented $13.1 \%$ of total sample. Those who read Auto\& Design and medicine represented $1.8 \%, 2.1 \%$ and $3.7 \%$ respectively. According to the above, college of Social and Management Sciences represented $12.1 \%+24.7 \%=37.8 \%$ put together.
College or faculties that have no skills or technical knowledge within their university programmes are : Law- 2.1\%. Management Sciences- 24.0\%. Soc. Sciences- $12.0 \%$, Education-8.0\%, and Humanities$7.1 \%$.

Natural sciences and related course were supposed to be laboratory based education, and these sets of graduates should have received the needed laboratory background training. However this was not so, none of them was ever exposed to the 
rudiment of the important area of their choice of courses, and since their interest was relegated to the whim and caprices of the university authority that continue to feed them on an old, obsolute, and redundant sort of wobbly and bookish courses. (See table 3 above for percentage share of the faculty courses).

Table 4. Level of qualification analysis.

\begin{tabular}{lllllll}
\hline Qn/LOC. & HND & & F.D. & & H.D \\
\hline & A & B(HND $)$ & C & D(FD\%) & E & F(HD\%) \\
OG 244 & 28 & 11.5 & 213 & 87.2 & 3 & 1.2 \\
OY 243 & 61 & 25.1 & 179 & 73.7 & 3 & 1.2 \\
KW 207 & 106 & 51.2 & 94 & 45.4 & 7 & 5.4 \\
EK 191 & 43 & 22.7 & 145 & 76.7 & 1 & 0.5 \\
ON 189 & 47 & 25.4 & 136 & 73.5 & 2 & 1.1 \\
OS 180 & 32 & 17.8 & 145 & 80.5 & 3 & 1.7 \\
LA 85 & 5 & 5.9 & 80 & 94.1 & - & 0.0 \\
T=1339 & 322 & 24.2 & 992 & 74.4 & 19 & 1.4 \\
\hline
\end{tabular}

Percentage of Respondents in all the seven states (put together) that responded to the questionnaire by level of qualification:- (i) $\mathrm{HND}=24.2 \%, \mathrm{FD}=74.4 \%$, andHD $=1.4 \%$. In columns, 3,5 and 7 respectively.

It can be seen that First Degree holders are three times higher than the HND holders whilst the number of Higher Degree holders are so infinitesimal, only $1.4 \%$.
A corper hold a degree of DSc. Economics, among the respondents from Ogun state. Three corps members hold a PhD. Degree each in Accounting, Law, and Optometry respectively from among the respondents from osun state secretariat. One corps member hold a $\mathrm{PhD}$. In Law from among the respondents from Kwara state. The fifth $\mathrm{PhD}$. degree holder in Philosophy was among the corps members respondents from Ekiti state secretariat.

Table 5: Educational qualification of respondents.

\begin{tabular}{lllll}
\hline Qualification table & Frequency & Percent & Valid \% & Cumulative \% \\
\hline HND & 322 & 24.2 & 24.2 & 24.2 \\
B Sc, B.A, BTech etc. & 992 & 74.4 & 74.4 & 98.6 \\
MSc, M.A, PhD, DSc. etc. & 19 & 1.4 & 1.4 & 100.0 \\
Percentage Total & $=$ & 100.00 & 100.0 & \\
\hline
\end{tabular}

The above shows that $(74.4 \%)$ of the respondents obtained first degree of B.A, BSc. B.Tech. etc. This is followed by $(24.2 \%)$ respondents who were Higher
National Diploma graduates, while respondents with MSc. PhD and DSc. were the least represented $(1.4 \%)$.

Table 6. Marital status of respondents.

\begin{tabular}{llllc}
\hline Marital & Frequency & \% Per. & Valid percent & Cumulative \% \\
\hline Married & 254 & 19.7 & 19.7 & 19.7 \\
Single & 1,033 & 80.3 & 80.3 & 100.0 \\
Total & 1287 & 100.0 & 100.0 & \\
\hline
\end{tabular}

In terms of marital status, males' respondents that were married represented (19.7\%), while females constituted $(80.3 \%)$ of the sample. 


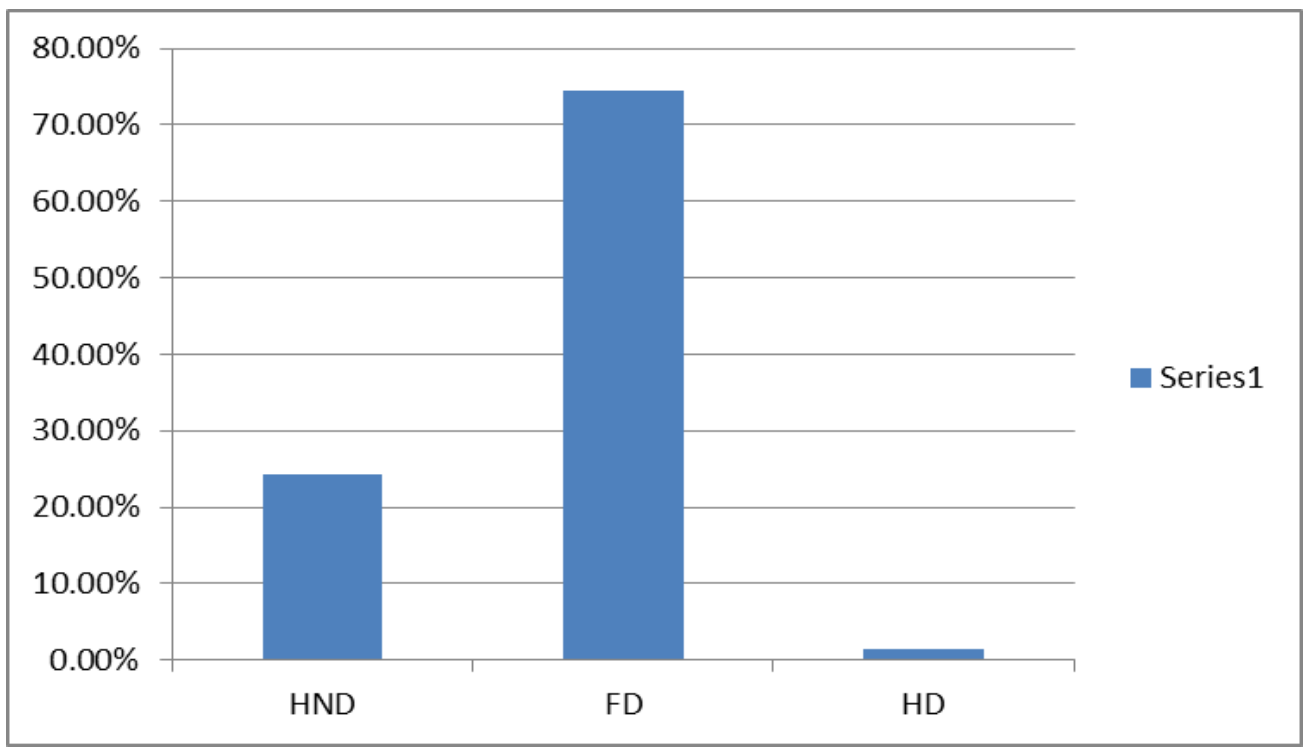

Figure 9. $\mathrm{HND}=$ Higher National Diploma, FD=First Degree and HD=MSc, Ph.D, and DSc degrees respectively.

Table 7. Age of respondents characteristics.

\begin{tabular}{lllll}
\hline Selected dimension & frequency & $\%$ & Valid \% & Cumulative \% \\
\hline $18-24$ & 308 & 31.9 & 31.9 & 31.9 \\
$25-29$ & 602 & 62.3 & 62.3 & 94.2 \\
$30-40$ & 56 & 5.8 & 5.8 & 100.0 \\
Total & 966 & 100.0 & 100.0 & \\
\hline
\end{tabular}

The above shows that greater proportion of the respondents are within the age range of 25-29 as represented by $(62.3 \%)$ endorsed that age range. This was followed by the age range $18-24$, representing
(31.9\%) of the total sample, while those between 3040 represented $(5.8 \%)$ of the total respondents. There were no respondents either under 18 years or above 40 years old that were represented in the survey.

Table 8. Sex of respondents.

\begin{tabular}{lllll}
\hline Gender & Frequency & $\%$ & Valid $\%$ & Cumulative $\%$ \\
\hline Male & 535 & 43.0 & 43.0 & 43.0 \\
Female & 709 & 57.0 & 57.0 & 100.0 \\
Total & 1244 & 100.0 & 100.0 & \\
\hline
\end{tabular}

In terms of the sex of the respondents, males represented $(43.0 \%)$ of the total sample, while the females constituted the highest percentage of $(57.0 \%)$ of the sample.

\section{Discussion}

It is pertinent to note that education can be a means to an end. It can also be a tool for securing employment and emancipation of people through the provision and acquisition of necessary knowledge and skills to make lives more nourishing. It should be noted that any entrepreneurship education strategy would require teachers to understand business and be trained in its different approaches - a proposition that may not find favour with the authority concerned. Undoubtedly there will be resistance from many quarters to such an initiative on introducing any new syllabi on culture, and can be a difficult and lengthy process. 
However, because it is challenging does not mean it cannot be achieved. Entrepreneurship education has not been fully integrated into the Nigeria university curriculum. Emphasis are laid (even those institutions running entrepreneurial program) on the conventional courses like in the Humanities, Natural sciences, Management sciences, Social sciences, arts, etc. hence, both lecturers and students have little or no knowledge about it(see table 2 and figures nos. 2 to 9).

Failure of tertiary education to inculcate the skills, technical, and business training philosophy in students has led to wastages in terms of both human and natural resources. This is because the youth and graduates from tertiary institutions are not equipped with the skills with which to exploit the natural resources that abound in Nigeria.

Irrelevant education that is bookish, theoretical and white collar job oriented, are being pursued or tenaciously adhered to by our universities. The availability of white collar jobs compared to the massive turnout of graduates as well as the NYSC members, showed a negative ratio.

The available jobs cannot meet the needs of over one hundred and fifty tertiary institutions (Fed, States, Private-Universities, Polytechnics, Colleges of Education) in Nigeria. A survey showed that these institutions graduate over 20,000 graduands each year. As of now, I know that minority of academics welcomes the development of entrepreneurship studies for the undergraduates to prepare them for the wide world of opportunities to create jobs and ultimately become employers of labour.

If you asks majority of university undergraduates today their plans for the future after graduation, many answers will surely tilt towards getting job in a wellestablished firm or institution, majority yearn for job in financial institutions or in oil producing companies. If one plots a graph to see the responses of undergraduate employment interest, it may be difficult to have up to $5 \%$ that will opt for skill/vocational career after their university education.

The problem can therefore be deposited at the door of the university authority and career counselors. But the bitter truth many are shying away from is that today university education failed in its calling to project into addressing the future of it students. Presently in Nigerian there are many public and private universities that fashion their curriculum after foreign educational policies to the detriments of Nigeria heritage and aspiration, this is not production driven at all.

Nigeria educational system planners should come out of their shells and develop an education template that can stand the test of time. The template should promote self discovery that dovetails into domestic manufacturing of essential goods locally, instead of engaging in impulsive importation of goods without recourse to the development of local manufacture of such materials.Bello-olowokere (2004) in his opinion sums it up that, the river that forgets its source will dry up. Means that Nigeria has short changed her heritage that should have been developed for the western world civilization. Today's education system in Nigeria should now go back to the drawing boards to redefine and overhaul the entire system for education renaissance.

It is time to make skill acquisition/ vocational education a compulsory requisite for graduation/part of graduation requirements in any institution of higher learning especially the universities in Nigeria. There is need to train student in the area of vocational/skills acquisition courses such as Paint making, link the university with foodstuff production, fruit juice manufacturing, printing inks, fashion design, screen print production, interior and exterior decoration etc. that can alleviate poverty caused by unemployment.

The kind of education Nigeria need today is that, that would help our people to think for themselves and employ their own hands in production and profitable ventures. There is the need to take this psychomotor aspect of our curriculum very seriously at all levels as well.

\section{Conclusion}

Finding revealed that entrepreneurial education is best received in the schools settings; also learning by doing is seen as the best approach or method to teach entrepreneurial education. The research also noted that being male or female has nothing to do with perception of the importance of entrepreneurial education within and outside the school system.

Employment should be made mandatory on the platform of having gone through any one vocational education training. It is not too late to plan now since it is better to be late than never. The authority in charge of education should face-up to the challenges and proffer a way out of quagmire of unemployment which has resulted to insecurity and economic instability in Nigeria.

The practice of educational policy in line with entrepreneurial education will develop students to give then job training in skills and professional fields as entrepreneurial education that will cover a whole range of activities. However entrepreneurship skills remain vital in the real sector and in the sustenance of economic development. It can be seen from this work that faculty of management sciences contributed a 
staggering graduate ratio of $24.0 \%$. For a college of social and management sciences put together, the ratio of graduates contributed as per this work gives $37 \%$. It means that in every one hundred graduates produced from our universities in a year, thirty-seven of them are from the faculties or colleges of social and management sciences only. Again courses such as management sciences, social sciences, humanities, law and education contributed percentage ratio of $24.0 \%, 12.8 \%, 7.1 \%, 1.7 \%, 8.1 \%$ respectively, which means that out of one hundred graduates from Nigerian universities, fifty-five of then are the products of these five colleges or faculties.

\section{Recommendation}

The paper recommended that educational programs at all levels should be made relevant to provide the youth the needed entrepreneurial skills. Also that government should give adequate attention to entrepreneurial development in the country through the provision of good economic environment.

The study therefore recommends that government in collaboration with all stake holders in education sector should ensure that entrepreneurial education is embedded into higher education curriculum. Thus the paper argues that entrepreneurial education will equip the students with the skills with which to be self-reliant.

\section{References}

Fairchild, D., Peirce, R., Kelly, M., Obana, J. Author Merrill Lynch Foundation Report (2000) "African-American Businesses" The next generation.

NYSC (Batches A,B \&C, (2012/2013), Ondo, Oyo, Ogun, Kwara, Ekiti, Osun, Lagos States respectively). Skills Acquisition State Secretariats' Units .

Isemede, J.O. (2012) "Export marketing management for competitive advantage" Pp1-3.

Cordelia, M (2011),"Entrepreneurship Education and Research: Emerging Trend and Concerns" Journal of Global Entrepreneurship.1(1).

Adebayo, O. (2011) "Curriculum contribution to the 5years BSc. Entrepreneurship design programme" Pp35-46. International Journal of Innovations in Management Science.

Raheem, S; Oyelola, O. T; Abe, J. B; Ajibosin, I. O and Igwe, C.N (2012),"Sustainability Entrepreneurship for sustainable Development" International Journal of Research and Sustainable Development.4(1), 129-135.

Oghene, C. K (2011), "Entrepreneurial Marketing: Key Component of Nigeria's Vision 2020" International Journal of Innovations in Management Sciences, .3(1),115-126.

Olabiyi, O.S (2012), "Preparing Youths for Entrepreneurial Challenges in Globalised World through Technical Vocational Education and Training" LASU International Conference on Entrepreneurial Education Pp54-60.

Muraina, I. O. Aiyegbusi, E. A. Lameed, S.N. Hassan, R. A. \& Olude, A. S. (2012) LASU International Conference on Entrepreneurship Education and Sustainable National Development." Entrepreneurship Education : A potential weapon to combat abject poverty in Nigeria" Pp 14-24.

Ayodele, Aderinwale (2012) LASU International Conference on Entrepreneurship Education and sustainable national development" Entrepreneurial education and sustainable national development" Pp 6-14. 